\title{
Evaluation of efficacy of collection techniques for human genomic DNA: MAOA-uVNTR polymorphism
}

\author{
M.S. Siva Prasad ${ }^{1 *}$ and Y Shibu Vardhanan ${ }^{2 *}$ \\ ${ }^{1,2}$ Toxicology and Biochemistry Laboratory, Department of Zoology, University of Calicut, Malappuram, India. \\ *Corresponding Author: svardhanan@gmail.com, Mobile: +919447108980
}

Available online at: www.isroset.org

Received: 03/Jun/2018, Revised: 09/Jun/2018, Accepted: 23/Jun/2018, Online: 30/Jun/ 2018

\begin{abstract}
For large scale DNA related studies it is necessary for non-invasive and cost-effective method for obtaining sufficient quantity and quality of DNA. In this study we collected buccal cells, dried blood and saliva from 10 participants by commercially available two types of foam swabs (Puritan and HiMedia), blood collection card (NucleoSave) and saliva collection kit (Oragene OG-500) respectively. Genomic DNA was extracted from the seven days old buccal cells and dried blood using QIAamp DNA Mini Kit (Qiagen) with a modification in the final elution step which resulted in high yield of DNA. Oragene DNA extraction protocol was followed to extract DNA from saliva. Integrity, yield and purity of extracted DNA were compared by agarose gel electrophoresis, spectrophotometry and PCR amplification success for specific gene. Though, the DNA yield was significantly greater from samples of saliva than buccal cells and dried blood, contamination was more in DNA from saliva. Purity of DNA obtained from buccal cells collected by Puritan foam swabs was better for the PCR reaction as evidenced by the successful amplification of 30-bp repeat polymorphism in the promoter of the MAOA gene. Hence, we conclude that Puritan foam swab is an ample and cost-effective method for collecting buccal cells for extracting genomic DNA for epidemiological and forensic studies.
\end{abstract}

Keywords - Saliva, buccal cell, dried blood, genomic DNA, PCR

\section{INTRODUCTION}

Since the cost of large-scale sequencing and genotyping is considerably less in recent years, there is increasing trends in applying these methods to various human populations, to investigate questions concerning forensics, population history, migrations, local adaptation, etc., [1]. A critical requirement for such large-scale population studies or for the forensic purpose is the quantity and quality of DNA extracted from the sample. In order to perform comparative DNA testing of the evidence collected from a crime scene, biological samples also should be obtained from suspects. Family reference samples may be used in paternity testing, missing person investigation and mass disaster victim identifications. Hence it is very important to maintain the integrity of the reference forensic samples until DNA analysis is performed.

As the yield of DNA is quite high (typically $10-15$ $\mu \mathrm{g} / \mathrm{mL}$ ) in whole blood and hence is the tissue of choice traditionally [2]. Obtaining blood sample is an invasive procedure that requires training in phlebotomy, it is painful for the donor and there are chances of infection too. These constraints limit the suitability of blood collection as a reference sample for some populations, which in turn has led to a search for alternative sources of DNA. Thus, many laboratories often use cheek swabs/ buccal swabs collection rather than drawing blood.

The ideal source of DNA reference sample should meet the following requirements: (a) the collection procedure should be easy, rapid and non-invasive (b) collection procedure should cause minimal inconvenience and be painless to the donor (c) in the case of field studies the sample should be able to store at ambient temperatures for days before DNA extraction is done (d) the loss of DNA quality should be minimal, and finally (e) DNA yield from the sample should be sufficient for a wide variety of applications [2].

For forensic purpose even though dried blood spots [3], plucked hairs [4] were also used; the yield of DNA is much less with these alternatives than with whole blood. Buccal swabs and saliva constitute the highest yielding of DNA, non-invasive alternative to whole blood [2,5]. For human DNA, saliva is potentially a very good source as the mean number of epithelial cells per $1 \mathrm{~mL}$ of saliva is about $4.3 \times 10^{5}$ [6], whereas the number of nucleated cells in $1 \mathrm{~mL}$ of whole blood is about 4.5-11 × $10^{5}$ [7]. On an average, every $2.7 \mathrm{~h}$, the surface layer of epithelial cells in mouth is replaced. Hence, the turnover of epithelial cells is quite extensive in the mouth, suggesting that there is likely to be intact genomic DNA in saliva and buccal samples [6]. Moreover, human genomic DNA can be reliably obtained from saliva $[6,7,8]$ and buccal cells $[9,10,11]$. Thus the quantity and quality of human genomic DNA obtained from saliva is normally sufficient for genetic analysis experiments and association studies $[2,8,11]$. The main drawback of saliva is the presence of bacterial cells, approximately $1.7 \mathrm{x}$ $10^{7} / \mathrm{mL}$ of saliva [6]. 
$50 \mathrm{ng}$ or more of genomic DNA per marker is typically required in a PCR reaction for amplifying microsatellite markers in a candidate gene and for linkage studies $[12,13]$. The concentration and purity of genomic extracted DNA are typically measured by spectrophotometric absorbance of ultraviolet light at wavelengths of 260, 230 and $280 \mathrm{~nm}$. The ratio of absorbance of about 1.8 for the optical density (OD) at $260 \mathrm{~nm} / 280 \mathrm{~nm}$ is considered to be the presence of high quality of nucleic acid with less protein and organic contamination. A higher value ( 2.0- 2.2) for the ratio of absorbance for the OD at $260 \mathrm{~nm} / 230 \mathrm{~nm}$ is preferred, which indicates limited salt and alcohol contamination [8, 14]. It is estimated that for PCR amplification reactions of majority of polymorphisms, DNA fragments of nearly $1 \mathrm{~kb}$ is only required and the quality of genomic DNA can also be measured using PCR success [11].

The potential uses of human DNA are expanding rapidly and hence we have compared the integrity, yield and purity of genomic DNA extracted from buccal cells, dried blood and saliva samples collected by commercially available collection materials. The samples were stored for up to seven days at room temperature. Integrity, yield and purity of extracted genomic DNA were assessed by agarose gel electrophoresis and spectrophotometrically. The main purpose of collecting DNA was for the future genotyping studies; hence the quality of DNA was also assessed using PCR amplification with primers specific for MAOA-uVNTR polymorphism.

\section{MATERIALS AND METHODS}

\section{Participants}

For this study, the participants $(\mathrm{N}=10)$ were male volunteers studying in various departments of University of Calicut. This research was a part of the pilot study about the association between MAOA-uVNTR polymorphism and violent behavior in recidivist offenders. This study was approved by the Institutional Ethics Committee, Calicut University Human Ethical Committee (Ref. No.: 003/CUEC/CR/2013-12-CU dated 25.04.2014). Informed written consents were obtained from all the participants.

\section{Sample collection}

Buccal epithelial cells were collected using two sterile swabs per participant. One swab was 'Sterile Foam Tipped Applicator' from Puritan, USA, with plastic handle and dry transport system. Other was 'Sterile Foam Tipped Swab' from HiMedia Laboratories Pvt. Ltd., India. All the participants were asked to desist from eating or drinking 1 hour prior to buccal cell collection. The scholar brushed inside of each cheek of each participant for $45 \mathrm{~s}$ with each sterile swab. Blood was collected from same participants on blood sample storage card, 'NucleoSave' from MachereyNagel GmbH \& Co. KG, Germany. Finger puncture method was followed to collect blood using a sterile lancet. Aseptic conditions were maintained while blood collection.
Whole saliva was collected from same ten participants using whole-saliva collection kit 'Oragene DNA (OG-500)' from DNA Genotek, Inc., Ottawa, Ontario, Canada, following the manufacturer's protocol. Four hour after the buccal swabs collection, approximately $2 \mathrm{~mL}$ saliva was deposited by the participants into the collection cup. The cap attached along with the collection cup was securely fastened after the collection of sufficient quantity of saliva, so that solution stored in the cap was released and mixed with the saliva. Buccal cells, blood and whole-saliva were collected from the participants on the same day. Buccal swabs and blood storage cards were air dried immediately after the sample collection and stored at room temperature for seven days including the saliva samples.

\section{DNA Extraction and Quantification}

\section{Buccal swab}

Swab containing tip along with the plastic handle was cut using a sterile scissor and was placed in $1.5 \mathrm{~mL}$ microcentrifuge tube. $400 \mu 1$ phosphate buffered saline $(\mathrm{pH}$ 7.4) was added to the samples. DNA was extracted from the buccal cells using the QIAamp DNA Mini Kit (Qiagen) following the Buccal swabs protocol with minor modifications in the final elution step. The final elution was done in two steps by adding $75 \mu \mathrm{l}$ Buffer $\mathrm{AE}$ and centrifuged at 8,000 rpm for $1 \mathrm{~min}$ instead of elution in single step by adding 150 $\mu 1$ Buffer AE. Also, Buffer AE was heated for 60 ${ }^{\circ} \mathrm{C}$ before adding to the QIAamp Mini spin column. After adding the heated buffer AE, the column was incubated at room temperature for $10 \mathrm{~min}$ in the modified steps before centrifugation. Eluted DNA was stored at $-20^{\circ} \mathrm{C}$ until further use.

\section{Dried blood}

From the centre of blood soaked area of NucleoSave, $0.5 \mathrm{~cm}^{2}$ area was cut using a sterile surgical blade and added to 1.5 $\mathrm{mL}$ microcentrifuge tube. Genomic DNA was then eluted using the QIAamp DNA Mini Kit (Qiagen) following the dried blood spots protocol with the same modifications in the final elution step as mentioned above in the case of buccal swab.

\section{Saliva}

Isolation of genomic DNA from whole-saliva collected in Oragene DNA (OG-500) kit was done as per the manufacturer's protocol. Extracted DNA was dissolved in $100 \mu \mathrm{l}$ Buffer AE provided in QIAamp DNA Mini Kit (Qiagen) and stored at $-20^{\circ} \mathrm{C}$.

\section{DNA Yield and Quality}

The yield and quality of genomic DNA extracted from the buccal cells, dried blood and saliva were determined using UV spectrophotometry (Eppendorf BioSpectrometer ${ }^{\circledR}$ basic 6135 , Germany) following the manufacturer's instructions.

\section{Agarose gel electrophoresis}


The integrity of extracted DNA was evaluated by running 8 $\mu 1$ of each sample on $0.9 \%$ agarose gel supplemented with ethidium bromide (10\% final concentration) (Sigma Aldrich) in TBE buffer ( $890 \mathrm{mM}$ Tris base, $890 \mathrm{mM}$ Boric acid, 0.5 $\mathrm{M}$ EDTA at final $\mathrm{pH} 8.3$ ) at a constant current at $105 \mathrm{~V}$ for 45 min. Bands of DNA were visualized in Gel documentation system (G: BOX, F3, SYNGENE, UK) for examining the extend of DNA degradation and digital photographs were taken. The bands were compared against $1.5 \mathrm{~kb}$ known molecular weight marker (50 DNA ladder, HiMedia).

\section{PCR Amplification}

PCR amplification for the 30-bp repeat polymorphism in the promoter of the MAOA gene was performed using PCR Master Mix (Qiagen HotStarTaq Master Mix Kit) in $12.5 \mu 1$ reaction volume containing a final concentration of $1.5 \mathrm{mM}$ $\mathrm{MgCl}_{2}$, 1x PCR Buffer, $200 \mu \mathrm{M}$ of each dNTP, 2.5 units HotStarTaq DNA Polymerase, $0.5 \mu \mathrm{M}$ of each primer and 1 $\mu 1$ extracted DNA. Previously published primer (Sigma Aldrich) sequences for MAOA-uVNTR were used, MAOaPT1:5'ACAGCCTGACCGTGGAGAAG-3' (forward primer), MAOaPB1: 5'-GAACGGACGCTCCATTCGGA-3' (reverse primer) [15]. PCR reactions were conducted in the thermal cycler (SureCycler 8800, Agilent Technologies, USA) with cycling conditions consisted of an initial denaturation of $95^{\circ} \mathrm{C}$ for 15 minutes, 35 cycles each consisting of 1 minute at $95^{\circ} \mathrm{C}, 1$ minute at $62^{\circ} \mathrm{C}$ and 1 minute at $72^{\circ} \mathrm{C}$. Final extension was continued for 10 minutes at $72^{\circ} \mathrm{C}$ after the last cycle. Amplification of the desired sequence was confirmed by running $6 \mu \mathrm{l}$ PCR products in $2 \%$ agarose gel supplemented with ethidium bromide (10\% final concentration) (Sigma Aldrich) in TBE buffer. Bands of amplified products were visualized in Gel documentation system and sizes were compared against 50 bp DNA Ladder (Thermo Scientific) with visible bands of length 1000, 900, 800, 700, 600, 500, 400, 300, 250, 200, $150,100,50 \mathrm{bp}$. Remaining quantity of PCR products were stored at $4^{\circ} \mathrm{C}$ in a refrigerator until sequenced.

\section{Data analysis}

Statistical analyses of the data were performed using SPSS 20 for Windows. The yield and purity of DNA extracted from samples collected by four different collection methods were compared by one- way ANOVA followed by post hoc Scheffe test performed at 0.05 level of significance.

\section{RESULTS AND DISCUSSION}

Yield and integrity of DNA extracted from ten participants were checked by agarose gel electrophoresis (5 DNA samples each from four methods of collection). Degradation was observed more for the DNA from saliva samples with long smear when compared to the sharp bands in buccal cell
DNA. No sharp bands were observed in the case of DNA from dried blood (Figure 1).

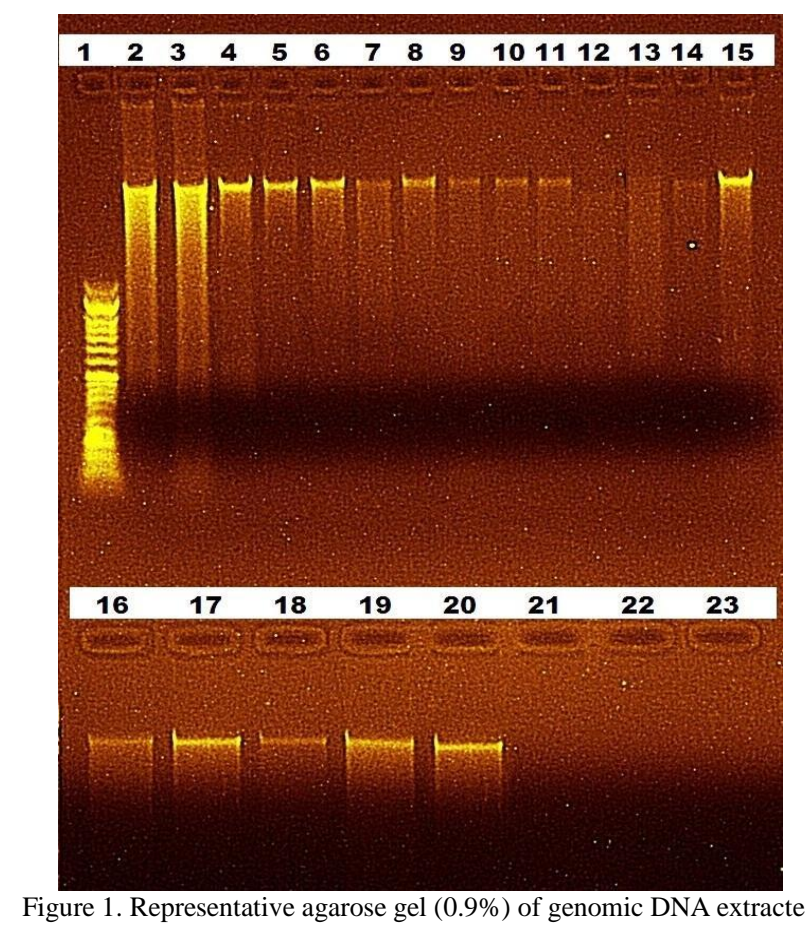
from saliva, buccal cells and dried blood.

Lane 1 contains 50 bp DNA ladder (HiMedia) of 17 bands ranging in size from 50 to $1500 \mathrm{bp}$, with bold reference bands of 200, 500 and 1200 bp. Lanes 2-6, 7-11, 16- 20 were DNA extracted from saliva (Oragene OG-500), buccal cells from (HiMedia foam swabs) and Puritan foam swabs respectively. Lanes 12- 14, 21 and 22 were DNA extracted from dried blood (NucleoSave). Lane15 and 23 were positive control and blank respectively. $8 \mu \mathrm{l}$ of DNA was mixed with $2 \mu \mathrm{l} 6 \mathrm{X}$ agarose DNA loading dye prior to loading the gel.

The yield and purity of extracted DNA was estimated spectrophotometrically also. One-way ANOVA was performed to identify the mean difference in the yield of DNA from four collection methods. The average yield of DNA was found to be different across sections, $F(3,36)$ $=1354.55, p<0.00$. The Scheffe multiple comparisons performed at the 0.05 significance level found that the mean yield of genomic DNA extracted from saliva (Oragene, OG500) $(M=362.70, S D=28.23, N=10)$ was significantly greater than all other sample types in this study. There was statistically significant difference in the mean yield of DNA from buccal cells collected by Puritan foam swab $(M=$ 43.86, $S D=8.15, N=10)$ than HiMedia $(M=17.36, S D=$ 3.06, $N=10)$ foam swab and dried blood collected on NucleoSave $(M=0.7, S D=0.24, N=10)$. Specifically, the Puritan swab seems to have better average DNA yield than the HiMedia swab and NulceoSave. It was observed that 
high quantity of DNA was able to be extracted from all the buccal cells and dried blood with a modification in the final elution step in the DNA extraction protocol of Qiagen (Table $1)$.

\begin{tabular}{|l|c|c|c|c|}
\hline $\begin{array}{l}\text { Method } \\
\text { of } \\
\text { collection }\end{array}$ & $\begin{array}{c}\text { Puritan } \\
\text { Foam } \\
\text { Swab }\end{array}$ & $\begin{array}{c}\text { HiMedia } \\
\text { Foam } \\
\text { Swab }\end{array}$ & NucleoSave & $\begin{array}{c}\text { Oragene (OG- } \\
\text { 500) }\end{array}$ \\
\hline Sample & Buccal cells & Buccal cells & Dried blood & Saliva \\
$\mathrm{N}^{*}$ & 10 & 10 & 10 & 10 \\
$\mathrm{M} \pm \mathrm{SD}$ & $43.86 \pm 8.15^{2,6}$ & $17.36 \pm 3.06^{2}$ & $0.70 \pm 0.24^{2}$ & $362.70 \pm 28.23^{3,4,5}$ \\
Median & 44.30 & 15.90 & 0.70 & 372.00 \\
Minimum & 32.20 & 14.00 & 0.40 & 314.00 \\
Maximum & 56.40 & 22.30 & 1.00 & 390.00 \\
\hline
\end{tabular}

$\mathrm{N}^{*}=$ Number of participants, $\mathrm{M}=$ Mean, $\mathrm{SD}=$ Standard Deviation

( ${ }^{l}$ Mean DNA yields were compared using One-way ANOVA. Scheffe was done for multiple comparisons; ${ }^{2}$ Significantly different from Oragene (OG-500); ${ }^{3}$ Significantly different from Puritan Foam Swab; ${ }^{4}$ Significantly different from HiMedia Foam Swab; ${ }^{5}$ Significantly different from NucleoSave; ${ }^{6}$ Significantly different from HiMedia foam swab and NucleoSave.)

Purity of DNA can be affected by methods of collection (integrity and protein contamination) and extraction techniques (alcohol, salt and organic, and protein contamination). The overall ANOVA results for the average purity of DNA was different across collection methods, $F$ ${ }_{\text {(A260/A280) }}(3,36)=7.17, p=0.01 ; F_{(\text {A260/A230) }}(3,36)=357.63, p$ $<0.00$. Mean ratios of $\mathrm{A}_{260} / \mathrm{A}_{280}$ and $\mathrm{A}_{260} / \mathrm{A}_{230}$ for DNA extracted from dried blood were $1.81 \pm 0.04$ and $2.03 \pm 0.03$ respectively. This was in the criterion range $(\sim 1.8$ and $\sim 2.0$ 2.2 respectively) which shows that the quality of DNA was high. Contamination was high in the DNA extracted from saliva $\left(\mathrm{A}_{260} / \mathrm{A}_{280}\right.$ ratio $=1.65 \pm 0.07 ; \mathrm{A}_{260} / \mathrm{A}_{230}$ ratio= $1.06 \pm$ 0.07). It was found that when compared with saliva, the contamination of DNA was significantly less from buccal cells collected by Puritan $\left(\mathrm{A}_{260} / \mathrm{A}_{280}\right.$ ratio $=1.74 \pm 0.10$; $\mathrm{A}_{260} / \mathrm{A}_{230}$ ratio $\left.=1.76 \pm .0 .05\right)$ and HiMedia foam swabs $\left(\mathrm{A}_{260} / \mathrm{A}_{280}\right.$ ratio $=1.71 \pm 0.08 ; \mathrm{A}_{260} / \mathrm{A}_{230}$ ratio= $\left.1.71 \pm 0.09\right)$. Also, there was not much difference in the purity between these collection methods (Figure 2).

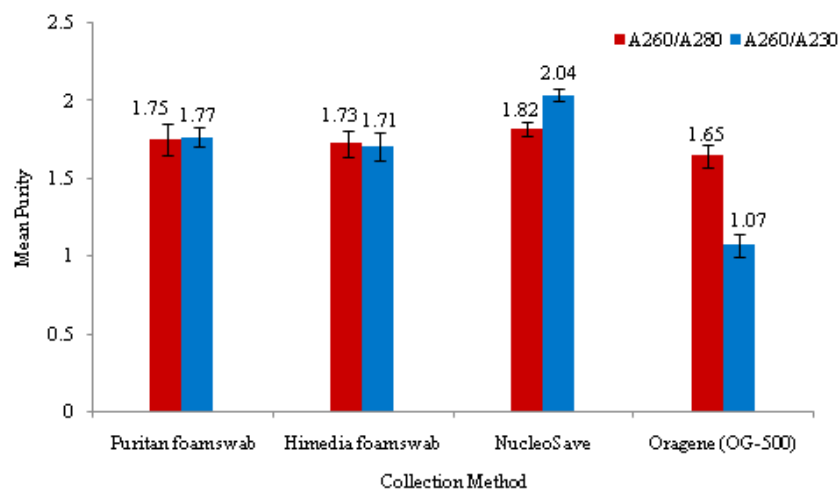

Figure 2. Comparison of mean purity of DNA from collection methods
A260/A280, ratio of absorbance at $260 \mathrm{~nm}$ to absorbance at $280 \mathrm{~nm}$ shows the measure of protein and organic contamination. A260/A230, ratio of absorbance at $260 \mathrm{~nm}$ to absorbance at $230 \mathrm{~nm}$ shows the measure of salt and alcohol contamination.

As the main purpose of collecting DNA in this study was for future genotyping, the quality of extracted genomic DNA was also assessed by PCR success using primers specific for $M A O A-\mathrm{uVNTR}$ polymorphism. The expected size of the amplified PCR products of allelic variants of $M A O A-\mathrm{uVNTR}$ polymorphism approximately ranges from 294 bp to 384 bp [16]. The above mentioned 20 DNA samples were subjected to PCR amplification and fragments were identified concordant in agarose gel electrophoresis (Figure 3). The success rate was $100 \%$ with the extracted genomic DNA from all samples as a template for the PCR reaction.

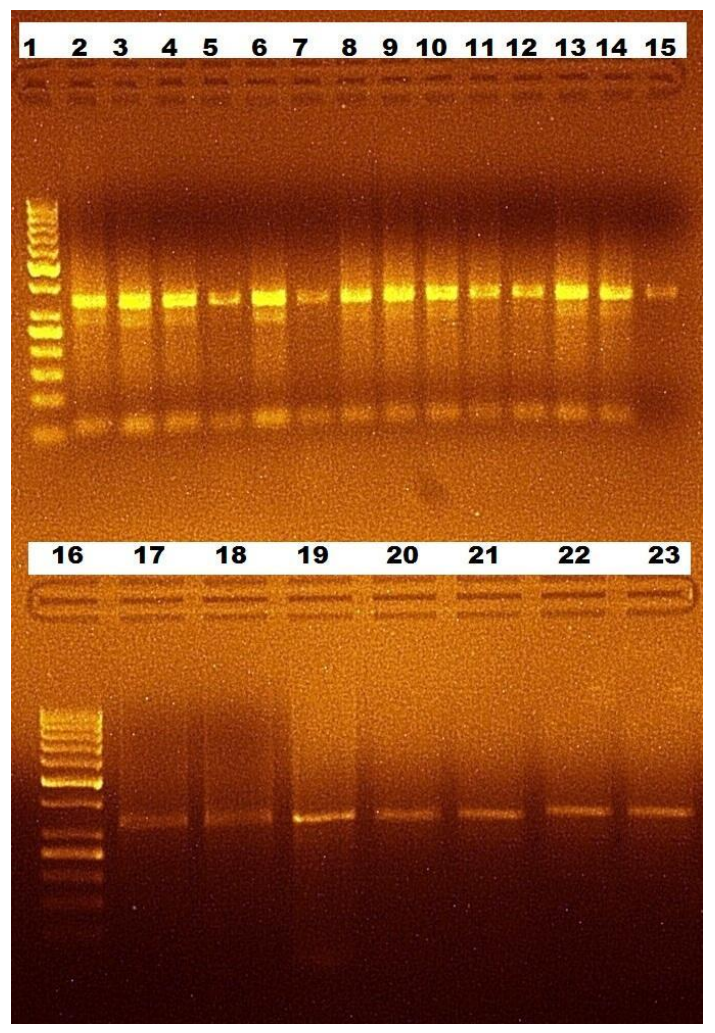

Figure. 3. Representative agarose gel (2\%) of MAOA-uVNTR polymorphism PCR products from genomic DNA

Lane 1 and 16 contains 50 bp DNA ladder (Thermo Scientific) of 13 bands, with bold reference band of $250 \mathrm{bp}$ and 500 bp. Lanes 2-6, 7- 11, 12- 15 and 17; 18- 22 were PCR products generated from DNA extracted from buccal cells collected by 'Puritan' and 'HiMedia' foam swabs, dried blood on 'NucleoSave' and saliva in 'Oragene OG-500' respectively. Lane 23 was a positive control of MAOA$\mathrm{uVNTR}$ polymorphism. $6 \mu \mathrm{l}$ of PCR reaction mix was mixed 
with $2 \mu 16 \mathrm{X}$ agarose DNA loading dye (Thermo Scientific) prior to loading the gel.

\section{Discussion}

All the samples were stored at room temperature and no refrigeration was done in order to mimic exact field conditions of the future study. This might have resulted in bacterial growth in saliva samples and the substantial amount of DNA from saliva sources could be of microbial origin [17, 18]. Though the manufacturer claims for only $6.8 \%$ of median bacterial content in saliva collected in Oragene DNA (OG-500) kit, we did not go for any human DNA assay since it is difficult and expensive. Even if high molecular weight DNA was able to be extracted from saliva collected in Oragene DNA (OG-500) kit, the integrity and purity were less and it may be due to DNA degradation, carry over food particles and ethanol residues in the Oragene DNA extraction protocol.

In agarose gel electrophoresis, DNA bands showed the intensity and sharpness depending upon the yield and level of degradation of DNA which were concordant to the spectrophotometric readings of the yield of DNA from the four collection methods.

Although this study has investigated about the best collection method of buccal/saliva/blood samples for genomic DNA extraction, it anticipated a higher yield of genomic DNA by following a modification in the elution step. Puritan foam swab provided ample yield of DNA. As the size and area of the foam was more in Puritan, the foam might be saturated with more cheek cells than in HiMedia foam swab and hence a higher yield of genomic DNA in comparison to later. The mean yield of DNA from buccal cells collected by Puritan foam swab in our study was much higher than the results from other studies using spit wads [19], buccal swabs [11, 20, 21] and cytobrushes [22, 23]. We could observe that the median yield of DNA from dried blood was also nearly four times higher than the quantity of DNA that extraction kit's manufacturer claims. Hence, the primary strength of this study was that the two step elution process with heated buffer AE, which increased the yield of DNA from foam swabs as well as blood collection card.

\section{CONCLUSION AND FUTURE SCOPE}

PCR amplification success showed that the quantity and quality of DNA extracted from buccal cells, dried blood and saliva was sufficient for short and intermediate amplification. Though the PCR amplification was success for all the samples, the intensity of bands of the PCR products of DNA from buccal cells collected by Puritan foam swabs showed more intensity than other PCR products. Also, when taken together the overall yield and purity of extracted DNA from Puritan foam swab were adequate for genotyping of MAOAuVNTR polymorphism. Hence, we conclude that the Puritan foam swab is an ample and cost-effective method for collecting buccal cells for extracting genomic DNA for epidemiological and forensic studies.

\section{CONFLICT OF INTEREST}

For this research paper there is no conflict of interest as confirmed by the authors.

\section{ACKNOWLEDGMENT}

Authors are thankful to University Grants Commission for the financial assistance through Senior Research Fellowship (SRF) and UGC-SAP programme of Department of Zoology, University of Calicut for the extending the laboratory facilities.

\section{REFERENCES}

[1] S.A. Tishkoff, B.C. Verrelli, "Patterns of human genetic diversity: implications for human evolutionary history and disease", Annual review of genomics and human genetics, Vol.4, Issue.1, pp.293340, 2003.

[2] D. Quinque, R. Kittler, M. Kayser, M. Stoneking, I. Nasidze, "Evaluation of saliva as a source of human DNA for population and association studies", Analytical biochemistry, Vol.353, Issue.2, pp.272-7, 2006.

[3] E.M. Rubin, K.A. Andrews, Y.W. Kan, "Newborn screening by DNA analysis of dried blood spots", Human genetics, Vol.82, Issue.2, pp.134-6, 1989.

[4] L. Vigilant, R. Pennington, H. Harpending, T.D. Kocher, A.C. Wilson, "Mitochondrial DNA sequences in single hairs from a southern African population", Proceedings of the National Academy of Sciences, Vol.86, Issue.23, pp.9350-4, 1989.

[5] B. Richards, J. Skoletsky, A.P. Shuber, R. Balfour, R.C. Stern, H.L. Dorkin, R.B. Parad, D. Witt, K.W. Klinger, "Multiplex PCR amplification from the CFTR gene using DNA prepared from buccal brushes/swabs", Human molecular genetics, Vol.2, Issue.2, pp.159-63, 1993.

[6] C. Dawes, "Estimates, from salivary analyses, of the turnover time of the oral mucosal epithelium in humans and the number of bacteria in an edentulous mouth", Archives of oral biology. Vol.48, Issue.5, pp.329-36, 2003.

[7] J.V. Dacie, "Dacie and Lewis practical haematology", Elsevier Health Sciences, Churchill Livingstone, UK, 2006.

[8] N.L. Rogers, S.A. Cole, H.C. Lan, A. Crossa, E.W. Demerath, "New saliva DNA collection method compared to buccal cell collection techniques for epidemiological studies", American Journal of Human Biology, Vol.19, Issue.3, pp.319-26, 2007.

[9] A. Brenton, C. Lee, K. Lewis, M. Sharma, S. Kantorovich, G.A. Smith, B. Meshkin, "A prospective, longitudinal study to evaluate the clinical utility of a predictive algorithm that detects risk of opioid use disorder", Journal of pain research, Vol.11, p.119, 2018.

[10] J. Buscaino, A. Barican, L. Farrales, B. Goldman, J. Klevenberg, M. Kuhn, F. Lin, P. Nguyen, S. Salceda, R. Schueren, C. Smith, "Evaluation of a rapid DNA process with the RapidHIT ${ }^{\circledR} I D$ system using a specialized cartridge for extracted and quantified human DNA", Forensic Science International: Genetics, Vol.34, pp.116-27, 2018.

[11] I.B. King, J.S. Abouta, M.D. Thornquist, J. Bigler, R.E. Patterson, A.R. Kristal, A.L. Shattuck, J.D. Potter, E. White, "Buccal cell DNA yield, quality, and collection costs: comparison of methods 
for large-scale studies", Cancer Epidemiology and Prevention Biomarkers, Vol.11, Issue.10, pp.1130-3, 2002.

[12] H. Buerger, H. Schmidt, A. Beckmann, K.S. Zänker, W. Boecker, B. Brandt, "Genetic characterisation of invasive breast cancer: a comparison of $\mathrm{CGH}$ and PCR based multiplex microsatellite analysis", Journal of clinical pathology, Vol.54, Issue.11, pp.83640, 2001.

[13] M.O. Hoque, C.C Lee, P. Cairns, M. Schoenberg, D. Sidransky, "Genome-wide genetic characterization of bladder cancer: a comparison of high-density single-nucleotide polymorphism arrays and PCR-based microsatellite analysis", Cancer research, Vol.63, Issue.9, pp.2216-22, 2003.

[14] K. Mackey, P. Chomczynski, "Effect of $p H$ and ionic strength on the spectrophotometric assessment of nucleic acid purity", Biotechniques, Vol.22, Issue.3, pp.474-481, 1997.

[15] S.Z. Sabol, S. Hu, D. Hamer, "A functional polymorphism in the monoamine oxidase A gene promoter", Human genetics, Vol.103, Issue.3, pp.273-9, 1998.

[16] M. Das, A. Das Bhowmik, S. Sinha, A. Chattopadhyay, K. Chaudhuri, M. Singh, K. Mukhopadhyay, "MAOA promoter polymorphism and attention deficit hyperactivity disorder (ADHD) in Indian children", American Journal of Medical Genetics Part B: Neuropsychiatric Genetics, Vol.141, Issue.6, pp.637-42, 2006.

[17] E.M. Heath, N.W. Morken, K.A. Campbell, D. Tkach, E.A. Boyd, D.A. Strom. "Use of buccal cells collected in mouthwash as a source of DNA for clinical testing", Archives of pathology \& laboratory medicine, Vol.125, Issue.1, pp.127-33, 2001.

[18] H.S. Feigelson, C. Rodriguez, A.S. Robertson, E.J. Jacobs, E.E. Calle, Y.A. Reid, M.J. Thun, "Determinants of DNA yield and quality from buccal cell samples collected with mouthwash", Cancer Epidemiology and Prevention Biomarkers, Vol.10, Issue.9, pp.1005-8, 2001.

[19] E.A. Ehli, T. Lengyel-Nelson, J.J. Hudziak, G.E. Davies. “Using a commercially available DNA extraction kit to obtain high quality human genomic DNA suitable for PCR and genotyping from 11year-old saliva saturated cotton spit wads", BMC research notes, Vol.1, Issue.1, p.133, 2008.

[20] B. Freeman, J. Powell, D. Ball, L. Hill, I. Craig, R. Plomin, "DNA by mail: an inexpensive and noninvasive method for collecting DNA samples from widely dispersed populations", Behavior genetics, Vol.27, Issue.3, pp.251-7, 1997.

[21] I. Meulenbelt, S. Droog, G.J. Trommelen, D.I. Boomsma, P.E. Slagboom, "High-yield noninvasive human genomic DNA isolation method for genetic studies in geographically dispersed families and populations", American journal of human genetics, Vol.57, Issue.5, p.1252, 1995.

[22] M. Garcia-Closas, K.M. Egan, J. Abruzzo, P.A. Newcomb, L. Titus-Ernstoff, T. Franklin, P.K. Bender, J.C. Beck, L. Le Marchand, A. Lum, M. Alavanja, "Collection of genomic DNA from adults in epidemiological studies by buccal cytobrush and mouthwash", Cancer Epidemiology and Prevention Biomarkers, Vol.10, Issue.6, pp.687-96, 2001.

[23] A.F. Saftlas, M. Waldschmidt, N. Logsden-Sackett, E. Triche, E. Field, "Optimizing buccal cell DNA yields in mothers and infants for human leukocyte antigen genotyping", American journal of epidemiology, Vol.160, Issue.1, pp.77-84, 2004.

\section{AUTHORS PROFILE}

Siva Prasad M.S received B.Sc degree in Medical Microbiology from Centre for Health Sciences, University of Calicut, Kerala, India (2009) and M.Sc degrees in Forensic Science from LNJN National Institute of Criminology $\&$ Forensic Science, Ministry of Home Affairs, New Delhi, India (2012). He has qualified the National Eligibility Test- Junior Research Fellowship (NET-JRF) examination conducted by University Grants Commission, India during the year 2011. He is now doing Ph.D research in the area of behavioural science in the Department of Zoology, University of Calicut, Kerala, India.

Dr. Y. Shibu Vardhanan, presently working as Associate Professor \& Head, Co-ordinator UGC-SAP, Department of Zoology, University of Calicut, Malappuram Kerala PIN: 673635. Currently focused on Geometric Morphometrics, toxicology and behavioural science.
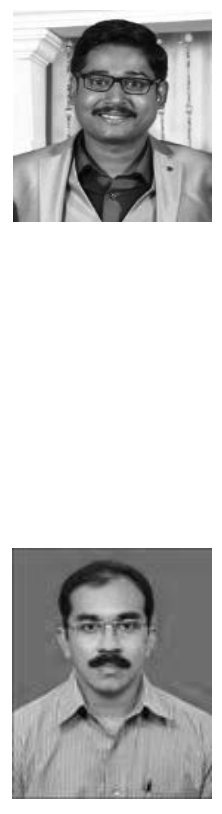